\title{
A catalyst of the bioengineering field plans its farewell
}

$T$ he Whitaker Foundation is closing its doors next year. The organization was set up in 1976 to award grants and support research and education, particularly in biomedical engineering, and was uniquely designed to have a finite life. Now, having completed its mission and achieved the goals it was set up to accomplish, the foundation has started to phase out its funding programs.

"Few foundations spend out," explained Frank Blanchard, director of communications at the Whitaker foundation. "I believe we are unique in not only spending out but being able to demonstrate a significant impact on the academic landscape."

Blanchard told the JCI that for years, the Whitaker Foundation was the only institution in the country that gave any organized support to the then up-andcoming field of biomedical engineering. The foundation has been instrumental in doubling the number of academic bioengineering departments, getting hundreds of biomedical engineers started in their careers, and building an infrastructure that will serve the field for years to come. The foundation drew so much attention to the emerging field that other funding agencies soon added their support. As a result, bioengineering evolved from an undeveloped new area to become the well-established yet still expanding discipline it is today.

Because the foundation has played such a big role in taking bioengineering into the academic mainstream, the question of why it would close it doors and what influence this termination will have on the future of the field looms large.

The vision of the Whitaker Foundation, as stated by its chairman, is that by 2006 , biomedical engineering will have evolved and gained acceptance to the point that it does not require this type of supplemental funding. At the foundation's inception, however, biomedical engineering investigators were having a hard time getting grants to fund their work.
"The grant was critical to me at that time of my career. I was not prepared to compete in the NIH arena for funding," says Peter Ma, who received a Whitaker Biomedical Engineering Research Grant for his work on cartilage scaffolds, used for tissue regeneration. "The Whitaker grant helped my career tremendously during the transition to $\mathrm{NIH}$-supported research directions," Ma says.

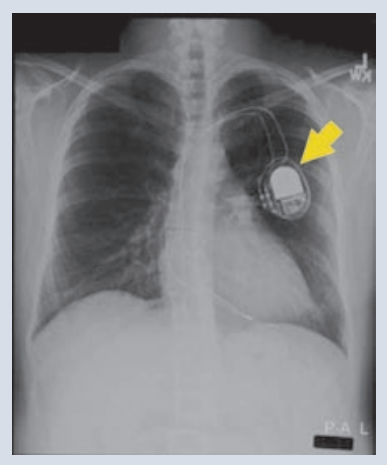

One of biomedical engineering's most important inventions, cardiac pacemakers are implanted in nearly one million people worldwide each year.

Darrell Irvine received one of the last Bioengineering Research Grants from the Foundation in 2003. Irvine, who studies immune cell interactions using synthetic collagen scaffolds, says, "I am still at the beginning of my career, and I had a limited track record and limited data. It [was] extremely unlikely that the NIH would have funded this work. Now we have exciting results that should be very convincing for obtaining future continued support through NIH."

Uncas A. Whitaker, in whose name the foundation was set up in 1975, hoped to benefit mankind with this trust and did not feel the need to create an organization in his name that would persist indefinitely. The committee at the time selected biomedical engineering as its primary focus because members believed the foundation could have a significant impact in that field by investing most of its resources over a short amount of time. Whitaker himself planned for a provision to prevent the private foundation from continuing beyond its purpose and becoming a bureaucracy.

It is not common for a private foundation to phase out like this. The last major foundation that supported biomedical research and spent out was the Lucille P. Markey Charitable Trust, which closed in 1997 after awarding more than $\$ 500$ million to medical schools and research institutes throughout the United States. There are a few other foundations spending out, such as the John M. Olin Foundation Inc., which supports economic, political, and cultural institutions.

The decision to shut down in 2006 was made by Whitaker's Governing Committee in 1991 . In these past 14 years, the foundation has stepped up its annual spending to $\$ 70$ million per year. This money has supported nearly 2000 students and faculty, has fostered educational programs, and has provided funds to construct new buildings to house biomedical engineering laboratories at several universities.

Gary Bowlin received his first major grant as principal investigator from the Whitaker Foundation in 1999. This grant afforded him the opportunity to be a pioneer in developing a technique called electrospinning to design tissue scaffolds, wound dressings, and hemostatic devices.

Surely medicine would be different today without tissue engineering, medical imaging, implantable materials, and other subfields of biomedical engineering spurred with funds from The Whitaker Foundation. The foundation was intended to be a driving force in catapulting the discipline into the forefront of science and medicine, and it has clearly succeeded in doing just that.

\section{Stacie Bloom}

